\title{
MODEL PEMBELAJARAN JUST IN TIME TEACHING (JITT) BERBANTUAN WEBSITE PADA TOPIK LISTRIK ARUS BOLAK-BALIK UNTUK MENINGKATKAN KETERAMPILAN BERPIKIR KREATIF SISWA SMA
}

\author{
Irwandani, M.Pd. ${ }^{1}$ \\ Program Studi Pendidikan Fisika IAIN Raden Intan Lampung \\ dirwansurya@yahoo.co.id
}

\begin{abstract}
Abstrak: Telah dilakukan penelitian dengan metode quasy experiment tentang penerapan pembelajaran JiTT berbantuan website untuk mengetahui peningkatanketerampilan berpikir kreatif siswa pada materi listrik arus bolak-balik. Sampel penelitian adalah siswa kelas X SMA tahun pelajaran 2012/2013. Sampel penelitian terbagi dalam dua kelas, yaitu kelas eksperimen dan kelas kontrol. Kelas eksperimen mendapatkan model pembelajaran JiTT berbantuan websitesedangkan kelas kontrol mendapat model pembelajaran JiTT tanpa bantuan website.Hasil uji statistik menunjukkan bahwakelas eksperimen secara signifikan lebih dapat meningkatkan keterampilan berpikir kreatif siswanyadibandingkan kelas kontrol. Dapat disimpulkan bahwa pembelajaran JiTT berbantuan website dapat lebih meningkatkan keterampilan berpikir kreatif siswa.
\end{abstract}

Kata kunci: Model pembelajaran JiTT, website, keterampilan berpikir kreatif

${ }^{1}$ Dosen Prodi Fisika Fakultas Tarbiyah dan Keguruan IAIN Raden Intan Lampung 


\section{Pendahuluan}

Fisika merupakan salah satu bagian dari ilmu alam yang penting untuk dipelajari di sekolah. Hal ini dikarenakan fisika dipandang sebagai ilmu dasar (pondasi) bagi pengembangan ilmu-ilmu lainnya seperti ilmu terapan, misalnya dalam bidang kedokteran, rekayasa teknik dan sebagainya. Selain itu, fisika juga dapat dipandang sebagai suatu disiplin ilmu yang mampu menghasilkan sejumlah keterampilan dan kemahiran generik pada siswa. Untuk mencapai hal tersebut, tentu diperlukan persiapan pembelajaran yang matang. Mulai dari perencanaan, pelaksanaan, hingga evaluasi haruslah disusun dengan baik dan disesuaikan dengan kurikulum yang berlaku, agar makna dan tujuan pembelajaran dapat tercapai.

Kurikulum Tingkat Satuan Pendidikan (KTSP) memberikan otonomi yang seluasluasnya kepada setiap satuan pendidikan (sekolah) untuk mengembangkan proses pendidikan sesuai dengan kebutuhan dan potensi masing-masing. Kurikulum ini membuka kepada segala hal baru yang dapat menunjang proses pembelajaran, termasuk pemanfaatan informasi dan teknologi. Selain itu, Peraturan Menteri Pendidikan Nasional (Permendiknas) Nomor 41 tahun 2007 mengharuskan bahwa proses pembelajaran yang dirancang berpusat pada peserta didik untuk mendorong motivasi, minat, kreativitas, inisiatif, inspirasi, kemandirian, dan semangat belajar. Berdasarkan hal ini, tentu akan membuka peluang pada semakin variatif dan inovatifnya pembelajaran di sekolah, khususnya pembelajaran fisika.

Namun, berdasarkan hasil observasi di salah satu sekolah menengah atas (SMA) diperoleh kenyataan bahwa mayoritas siswa masih menganggap pelajaran fisika adalah pelajaran yang sulit. Temuan ini diperkuat oleh hasil penelitian Saprudin (2010) yang mengatakan bahwa sebanyak 82\% siswa masih menganggap sulit pelajaran fisika. Menurut Ornek (2007) yang menjadi penyebab fisika sulit dipelajari oleh siswa dikarenakan pelajaran fisika dianggap pelajaran yang tidak menarik bagi mereka. Selain itu, konten fisika yang abstrak juga membuat mereka kesulitan dalam mempelajarinya.

Pembelajaran yang masih bersifat konvensional dan monoton disinyalir membuat sebagian besar siswa kurang tertarik mempelajari pelajaran fisika. Pembelajaran yang bersifat pasif ini tentu kurang mampu melatihkan siswa untuk menggunakan penalaran logis yang tinggi, terutama pada keterampilan berpikir tingkat tinggi (Armiza, 2007). Padahal keterampilan berpikir merupakan salah satu target yang harus dicapai oleh setiap siswa setelah pembelajaran, sebagaimana 
diamanatkan dalam kurikulum. Salah satu keterampilan berpikir tingkat tinggi yang masih jarang dilatihkan di sekolah adalah keterampilan berpikir kreatif. Beberapa hasil penelitian tentang keterampilan berpikir kreatif (Fitriana, 2010; Kaharu, 2010) menunjukkan bahwa nilai rata-rata keterampilan berpikir kreatif yang dimiliki siswa masih tergolong rendah.

Berdasarkan permasalahan yang telah dipaparkan di atas, maka perlu diadakan sebuah penelitian yang mampu memecahkan persoalan tersebut. Fokus utamanya berkenaan dengan upaya meningkatkan keterampilan berpikir kreatif siswa. Salah satu upayanya adalah dengan menggunakan pembelajaran yang berbasis teknologi dan informasi. Pembelajaran berbasis teknologi dan informasi ini mempunyai karakteristik yang dapat dikombinasikan dengan model pembelajaran apapun.Salah satunya denganmodel pembelajaranJust-in-Time Teaching (JiTT).Model pembelajaran JiTT merupakan model dan strategi pembelajaran yang memadukan antara penggunaan teknologi informasi dan pembelajaran aktif di kelas yang bersifat umpan balik antara siswa dan guru.Karena ada umpan balik antara guru dan siswa, maka dapat dikatakan bahwa JiTT mendorong pembelajaran yang berpusat pada siswa. Siswa dapat berinteraksi dengan sesama siswa, guru, dan teknologi yang dapat memaksimalkan keterampilan berpikir mereka dalam menemukan konsep.

Ada tiga tahapan utama dalam pembelajaran JiTT ini, yaitu tahap pemanasan, tahap penyesuaian konsep dan tahap penerapan konsep. Ketiga tahapan ini memberikan ruang pada siswa untuk aktif dan kreatif seperti saling bertanya, menjawab, berdiskusi, dan menyelesaikan masalah bersama sehingga mampu melatihkan kemampuan berpikir mereka. Hasil penelitian Solikhin (2012) menunjukkan bahwa pembelajaran JiTT mampu dalam meningkatkan keterampilan proses sains siswa.

Penggunaanmedia teknologi informasi dapat bersifat online maupun offline.Contoh dari media yang bersifat online adalah media website. Website atau situs web mengacu pada kumpulan file atau dokumen yang besar dan saling terkait yang dibuat tersedia untuk semua orang melalui internet (Mason \& Rennie, 2010). Media website sangat baik digunakan sebagai media pembelajaran, terutama pembelajaran fisika. Media ini dapat menjadi alternatif karena diyakini dapat menarik perhatian siswa terhadap pelajaran fisika. Mubaraq (2009) mengatakan bahwa pembelajaran yang berbasis website mampu menumbuhkan kemandirian siswa untuk mengkonstruksi sendiri pengetahuannya. Konten atau materi 
website disajikan dalam berbagai bentuk media atau sering disebut multimedia. Multimedia ini merupakan kombinasi dari tulisan, gambar, suara, animasi, simulasi, dan video yang disajikan sedemikian rupa sehingga menjadi produk media pembelajaran. Beberapa penelitian tentang penggunaan multimedia (Fitriana, 2010; Kaharu, 2010) menunjukkan adanya peningkatan keterampilan berpikir kreatif pada siswa.

Berdasarkan paparan di atas, penulis terdorong untuk melakukan penelitian tentang model Just-in-Time Teaching (JiTT) yang dipadukan dengan media website. Karena diharapkan dengan penggabungan itu, dapat meningkatkan keterampilan berpikir kreatif siswa. Adapun materi yang akan menjadi topik dalam penelitian ini adalah topik listrik arus bolak-balik untuk siswa kelas $\mathrm{X}$ SMA. Topik listrik arus bolak-balik dipilih karena di dalamnya banyak memuat konsep-konsep abstrak. Konsep yang abstrak ini jika ditampilkan dalam website melalui berbagai bentuk media diharapkan akan dapat membantu siswa untuk mengasah keterampilan siswa untuk berpikir kreatif.

\section{Kajian Pustaka}

\section{Model Pembelajaran JiTT berbantuan website}

Model Just-in-Time Teaching (JiTT) adalah strategipedagogisyangmenitikberatkan pada kemudahan teknologiuntuk meningkatkanpembelajaran siswa, membangun keterampilan, dan sikap (Patterson, 2005). Model pembelajaran JiTTberbantuan website merupakan gabungan antara model pembelajaran JiTT dengan website sebagai medianya. Media website dianggap mampu memfasilitasi tahapan JiTT dengan sangat baik. Seperti yang diungkapkan Formica (2010) yang mengatakan bahwa JiTT dapat menjadi sebuah model pembelajaran yang dapat memadukan penggunaan internet dan umpan balik (feedback) antara guru dan siswa, baik di dalam kelas maupun di luar kelas. Model pembelajaran JiTT terdiri dari tiga tahapan utama, yaitu tahap pemanasan, tahap penyesuaian konsep dan tahap penerapan konsep.

Adapun pengertian website sendiri mengacu pada kumpulan file atau dokumen, yang besar dan saling terkait, yang dibuat tersedia untuk semua orang melalui internet (Mason \& Rennie, 2010). Karena diakses melalui internet, maka pembelajarannya berlangsung secara online. Website memiliki topik saling terkait, terkadang di dalamnya disertai pula dengan berkas-berkas gambar, video, atau jenis-jenis berkas lainnya. Website dapat digunakan sebagai media belajar atau 
dikenal dengan istilah pembelajaran berbasis web. Sebelum digunakan sebagai media pembelajaran, terlebih dahulu website diisi materi pembelajaran dalam bentuk tulisan, gambar, video, animasi dan sebagainya yang kemudian disusun sedemikian rupa. Materi-materi tersebut dapat pula dihubungkan satu sama lain sehingga saling berkaitan (hyperlink) dan memungkinkan penggunanya untuk berpindah dari satu halaman ke halaman lain. Selain mampu menyediakan dokumen dengan bentuk yang bervariasi, website juga mampu melengkapi dirinya dengan fasilitas lain seperti ruang diskusi secara langsung (chatting) maupun tidak langsung. Bahkan juga mampu menghadirkan diskusi seperti tatap muka semisal teleconference.

Melihat kelebihan yang dimiliki oleh website, maka pada perkembangannya penggunaan website menjadi media yang favorit digunakan dalam pembelajaran JiTT. Namun, tidak sembarangan website bisa digunakan dalam pembelajaran JiTT. Novak (1999) menyebutkan bahwa syarat website yang akan diterapakan dalam pembelajaran JiTT haruslah mengandung 3 (tiga) hal berikut.

1. Tugas siswa sebagai persiapan untuk aktivitas dalam kelas (warm up and puzzle).

2. Halaman yang kaya akan informasi yang berisi artikel ringkas, aplikasi kehidupan sehari-hari yang terkait dengan konsep yang dipelajari, dan materi menarik lain yang terdapat di web lain.

3. Materi pembelajaran yang berdiri sendiri, seperti animasi, simulasi dan tugas terstruktur.

Untuk mengakomodasi tiga persyaratan tersebut, selanjutnya pada tataran teknis, konten dalam websiteyang sejalan dengan tahapan JiTT secara umum terbagi ke dalam tiga bagian utama, yaitu materi pelajaran, pertanyaan pemanasan dan ruang bertanya dan diskusi. Dalam penelitian ini, ruang diskusi disediakan dalam dua bagian, yaitu secara realtime seperti ruang chat dan tidak realtime seperti ruang bertanya dan menjawab. Untuk lebih jelasnya, alur pembelajarannya secara garis besar disajikan dalam Gambar 1. 


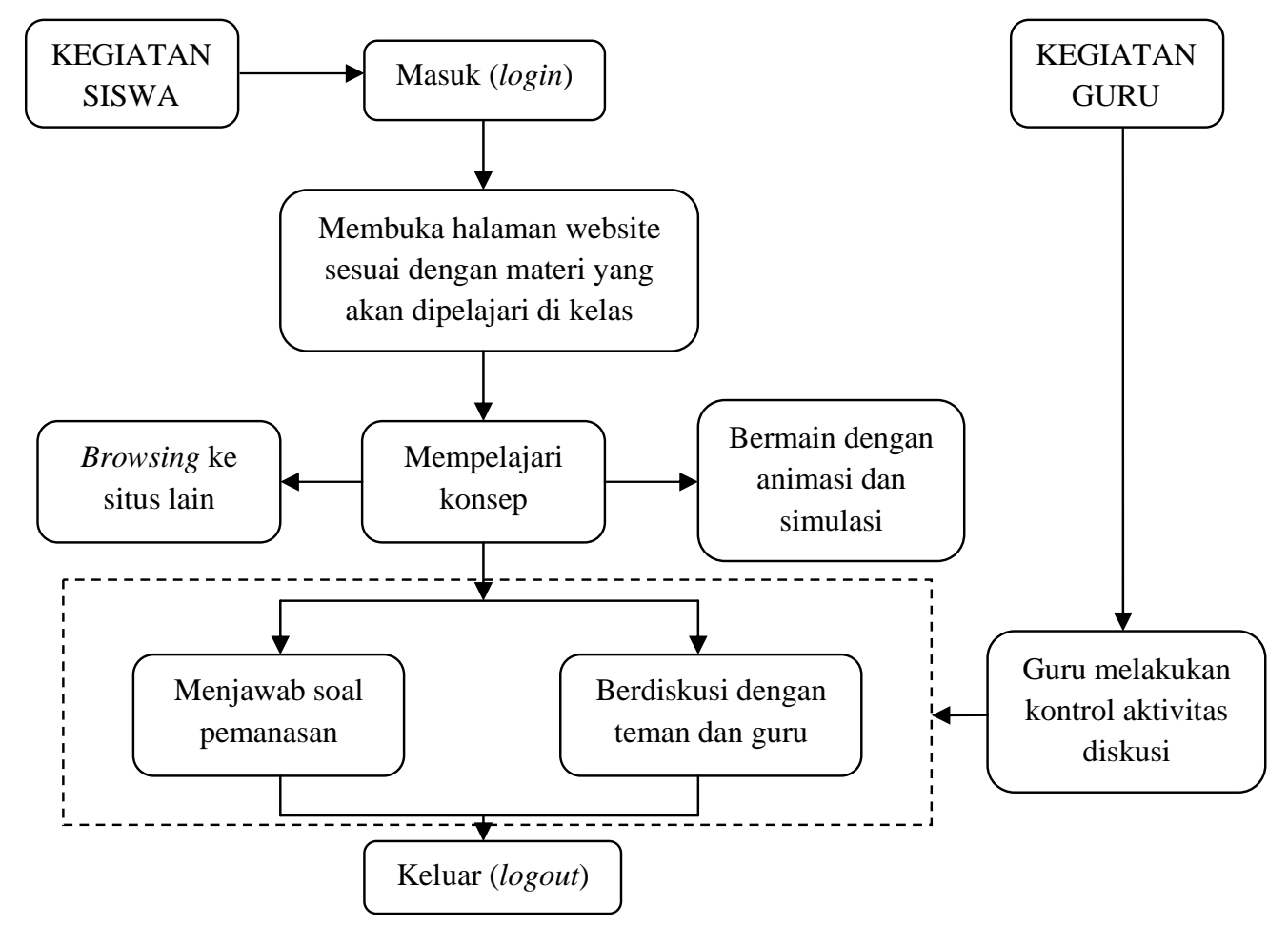

Gambar1. Alur Proses Pembelajaran JITT Berbantuan Website

\section{Keterampilan Berpikir Kreatif (KBK)}

Kreativitas atau daya cipta memungkinkan penemuan-penemuan baru dalam bidang ilmu dan teknologi, serta dalam semua bidang usaha manusia lainnya (Munandar, 2012). Berpikir kreatif dapat dikatakan sebagai sebuah kegiatan mental yang dialami seseorang bila mereka dihadapkan pada permasalahan yang harus dipecahkan. Hakikat berpikir kreatif adalah keterampilan dari pikiran untuk penciptaan ide atau gagasan baru.

Belajar kreatif tidak timbul secara kebetulan, melainkan memerlukan persiapan dari lingkungan kelas yang dapat merangsang siswa untuk belajar secara kreatif. Menurut Feldhusen dan Treffinger (Munandar, 1999) lingkungan kreatif dapat diciptakan melalui kegiatan pemanasan, pengaturan tempat duduk dalam kelas, melakukan diskusi dan kegiatan fisik dalam kelas serta guru yang dapat memfasilitasi.

Munandar (1999) menyebutkan ada 5 (lima) indikator utama dari keterampilan berpikir kreatif, yaitu keterampilan berpikir lancar (fluency), keterampilan berpikir luwes (flexibility), keterampilan berpikir orisinal (originality), keterampilan elaborasi (elaboration), dan keterampilan evaluasi (evaluation). 
1. Keterampilan berpikir lancar (fluency) Siswa yang memiliki keterampilan berpikir lancar yaitu siswa yang dapat mencetuskan banyak ide atau gagasan, jawaban, penyelesaian masalah, atau pertanyaan. Siswa juga dituntut untuk memberikan banyak cara atau saran untuk melakukan berbagai hal. Ciri perilaku dari keterampilan ini adalah siswa akan sering bertanya, menjawab pertanyaan, bekerja lebih cepat dan melakukan lebih banyak dibandingkan dengan yang lain. Selain itu, siswa yang memiliki keterampilan ini akan dengan cepat melihat kesalahan atau kekurangan pada suatu obyek atau situasi.

2. Keterampilan berpikir luwes (flexibility)

Keterampilan ini menuntut siswa untuk dapat mengemukakan berbagai pendekatan maupun solusi pemecahan terhadap suatu masalah. Siswa juga dituntut untuk mampu melihat suatu masalah dari sudut pandang yang berbeda-beda, mencari banyak alternatif, dan mampu mengubah cara pendekatan atau cara pemikiran.

3. Keterampilan berpikir orisinal (originality)

Keterampilan ini menuntut siswa untuk bisa mencetuskan suatu gagasan atau ide dengan cara-cara yang asli (original). Selain itu, siswa juga dituntut untuk mampu melahirkan ungkapan yang baru dan unik, memikirkan cara yang tidak lazim, maupun mampu membuat kombinasikombinasi yang tidak lazim dari bagian-bagian atau unsur-unsur. Keterampilan ini menuntut siswa untuk memiliki cara berpikir yang berbeda dengan yang lain, mampu menemukan penyelesaian baru dari sebuah bacaan atau gagasan.

4. Keterampilan elaborasi (elaboration) Keterampilan elaborasi adalah keterampilan untuk menguraikan segala sesuatu secara terperinci. Keterampilan ini menuntut siswa untuk mampu memperkaya dan mengembangkan suatu gagasan atau produk. Selain itu, siswa juga dituntut untuk bisa memperinci detil-detil dari suatu obyek, gagasan, atau situasi sehingga menjadi lebih menarik, mengembangkan atau memperkaya gagasan orang lain.

\section{Keterampilan evaluasi (evaluation)} Keterampilan evaluasi merupakan keterampilan yang melatih siswa untuk dapat menentukan patokan penilaian sendiri serta mampu mengambil keputusan terhadap situasi yang terbuka. Siswa yang memiliki keterampilan evaluasi dapat 
memberikan pertimbangan atas dasar sudut pandangnya sendiri, merancang suatu rencana kerja dari gagasangagasan yang tercetus, menganalisis masalah atau penyelesaian secara kritis, serta dapat mempertahankan pendapatnya secara rasional.

\section{Keterkaitan Sintaks JiTT dengan Aspek KBK yang Dilatihkan}

Tiga tahapan pembelajaran JiTT berbantuan websiteharus mampu melatihkan keterampilan berpikirkreatif siswa. Hubungan sintaks antara model pembelajaran JiTT berbantuan website dengan KBK dapat dilihatpada Tabel 1.

Tabel 1. Tahapan Pembelajaran dan Aspek yang Dilatihkan

\begin{tabular}{|c|c|c|}
\hline $\begin{array}{c}\text { Tahapan } \\
\text { Model JiTT }\end{array}$ & Kegiatan Pembelajaran & $\begin{array}{c}\text { Keterampilan Berpikir Kreatif } \\
\text { yang Dilatihkan }\end{array}$ \\
\hline \multirow{3}{*}{$\begin{array}{l}\text { Tahap } 1 \\
\text { Pemanasan }\end{array}$} & Membaca materi website & Berpikir lancar \\
\hline & Menjawab soal pemanasan & Berpikir luwes, orisinal, evaluasi \\
\hline & Diskusi dengan teman dan guru & $\begin{array}{l}\text { Berpikir luwes, orisinal dan } \\
\text { evaluasi }\end{array}$ \\
\hline \multirow{3}{*}{$\begin{array}{l}\text { Tahap } 2 \\
\text { Penyesuaian } \\
\text { Konsep }\end{array}$} & $\begin{array}{l}\text { Diskusi kelas terhadap soal } \\
\text { pemanasan }\end{array}$ & $\begin{array}{l}\text { Berpikir luwes, orisinal, dan } \\
\text { evaluasi }\end{array}$ \\
\hline & Mempelajari konsep & Berpikir lancar \\
\hline & Menggunakan animasi dan simulasi & Elaborasi, evaluasi \\
\hline \multirow{2}{*}{$\begin{array}{l}\text { Tahap } 3 \\
\text { Penerapan } \\
\text { Konsep }\end{array}$} & Diskusi pemecahan masalah & $\begin{array}{l}\text { Berpikir luwes, elaborasi, dan } \\
\text { evaluasi }\end{array}$ \\
\hline & Menggunakan laboratorium virtual & $\begin{array}{l}\text { Berpikir luwes, orisinal, dan } \\
\text { elaborasi }\end{array}$ \\
\hline
\end{tabular}

\section{Metode dan Desain Penelitian}

Penelitian ini menggunakan metode quasy experiment, sedangkan desain penelitiannya menggunakan The RandomizedPretest-Posttest Control Group Design (Fraenkel, 1993).Pada penelitian ini terdapat dua kelompok subjek penelitian, yaitu kelas eksperimen dan kelas kontrol. Masing-masing kelas diberi pretest yang dilakukan sebelum treatment dan posttest yang dilakukan setelah tiga pertemuan atau treatment dilakukan. Pada kelas eksperimen diberi treatment berupa model pembelajaran JiTT berbantuan website.Sementara pada kelas kontrol diberikan pembelajaran JiTT tanpa bantuan website. 
Populasi dalam penelitian ini adalah seluruh siswa kelas $\mathrm{X}$ di salah satu SMA di Kabupaten Indramayu semester genap tahun ajaran 2012/2013. Dari populasi dipilih dua kelas sebagai sampel menggunakan teknik cluster random sampling. Kelas yang dipilih menjadi kelas eksperimen memiliki jumlah siswa sebanyak 34 siswa. Sedangkan kelas kontrol memiliki jumlah siswa sebanyak 36 siswa.

\section{Hasil Penelitian}

Indikator keterampilan berpikir kreatif yang diteliti dalam penelitian ini meliputi keterampilan berpikir lancar, keterampilan berpikir luwes, keterampilan berpikir orisinal, keterampilan elaborasi, dan evaluasi. Peningkatan keterampilan berpikir kreatif baik pada kelas eksperimen maupun kelas kontrol secara umum dapat dilihat dengan membandingkan rata-rata nilai tes awal dengan tes akhir serta melihat nilai N-gain-nya.

Persentase pencapaian nilai rata-rata tes awal, tes akhir dan $\mathrm{N}$-gain untuk keterampilan berpikir kreatif siswa dari kelas eksperimen dan kelas kontrol ditunjukkan pada Gambar 2.

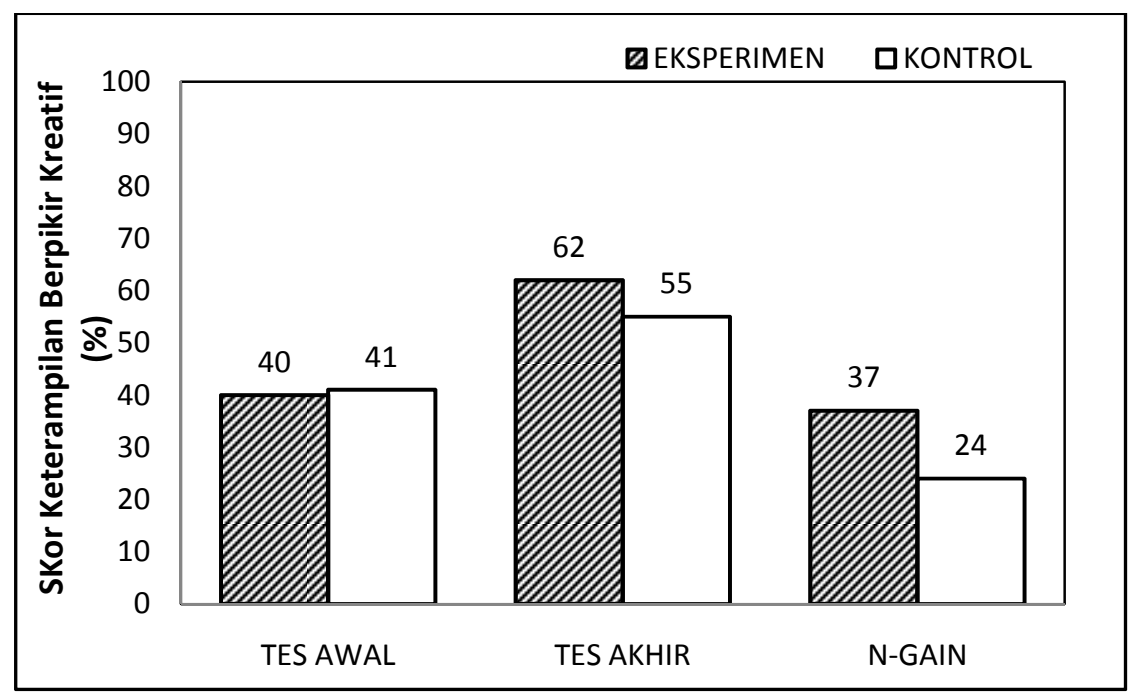

Gambar 2. Perbandingan Persentase Nilai Rerata Tes Awal, Tes Akhir dan N-Gain Keterampilan Berpikir Kreatif Siswa Kelas Eksperimen dan Kelas Kontrol

Berdasarkan Gambar 2 terlihat bahwa pencapaian nilai rata-rata tes awal keterampilan berpikir kreatif siswa kelas eksperimen sebesar 40\% dari nilai ideal. Sementara pada kelas kontrol mendapatkan nilai rata-rata tes awal sedikit lebih unggul dibanding kelas eksperimen, yaitu sebesar $41 \%$ dari nilai idealnya. Namun pada tes akhir, rata-rata nilai kelas eksperimen lebih tinggi 
dibanding kelas kontrol, yaitu sebesar 62\% dari nilai ideal. Sementara kelas kontrol hanya memperoleh rata-rata sebesar 55\% dari nilai ideal.

Selanjutnya, untuk melihat seberapa besar peningkatan keterampilan berpikir kreatif, dapat dilihat dengan membandingkan besarnya rata-rata $\mathrm{N}$-gain kelas eksperimen dan kelas kontrol. Ratarata $\mathrm{N}$-gain kelas eksperimen sebesar 0,37 (sedang) dan kelas kontrol sebesar 0,24 (rendah). Berdasarkan hasil perbandingan rata-rata tes awal, tes akhir dan $\mathrm{N}$-gain dapat dinyatakan bahwa peningkatan keterampilan berpikir kreatif kelas eksperimen lebih tinggi dibandingkan dengan kelas kontrol. Adapun perbandingan $\mathrm{N}$-gain dari tiap indikator keterampilan berpikir kreatif antara kelas eksperimen dan kelas kontrol dapat dilihat pada Gambar 3.

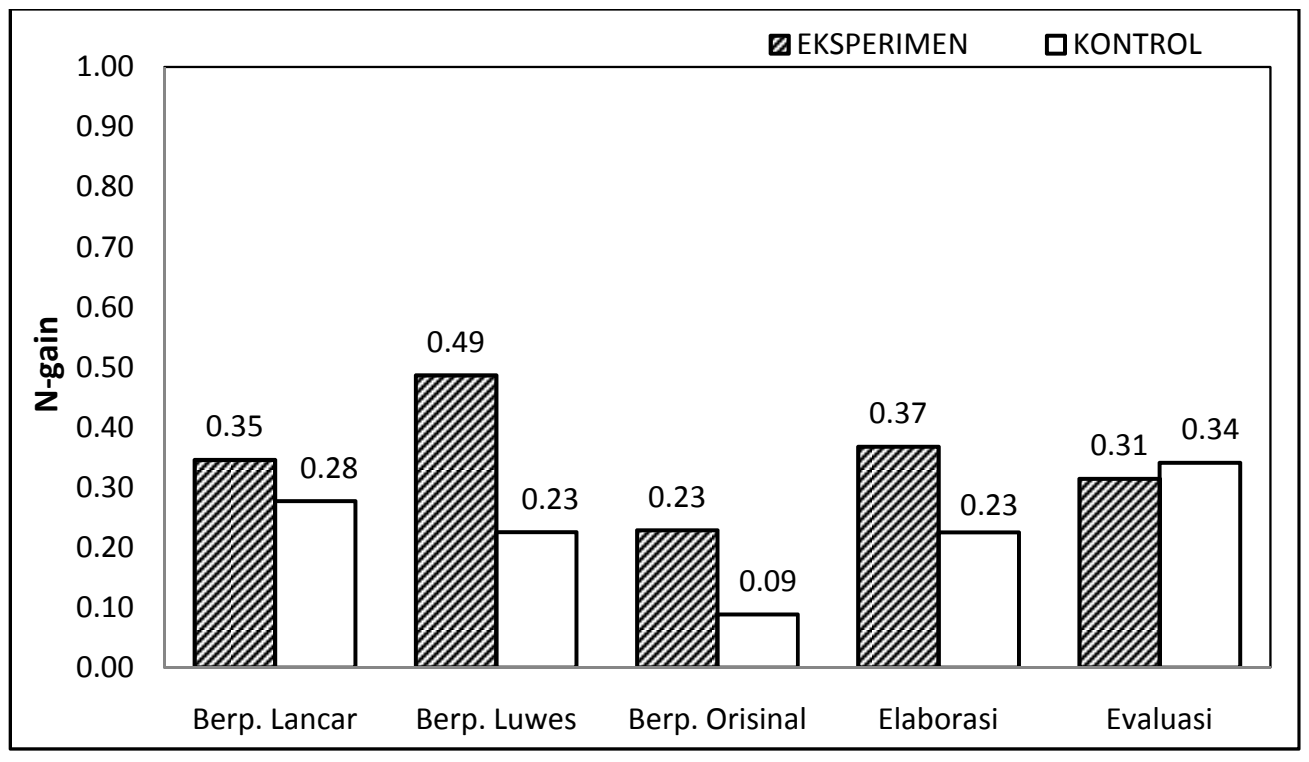

Gambar 3. Perbandingan N-Gain untuk Tiap Indikator Keterampilan Berpikir Kreatif

Antara Kelas Eksperimen dan Kelas Kontrol

pada indikator evaluasi yaitu sebesar 0,34

Berdasarkan Gambar 3, perolehan Ngain tertinggi pada kelas eksperimen terjadi pada indikator berpikir luwes yaitu sebesar 0,49 dengan kategori sedang. Sedangkan nilai terendah terjadi pada indikator berpikir orisinal sebesar 0,23 dengan kategori rendah. Sementara itu pada kelas kontrol $\mathrm{N}$-gain tertinggi terjadi dengan kategori sedang. Sedangkan nilai terendah terjadi pada indikator berpikir orisinal yaitu sebesar 0,09 dengan kategori rendah.

Secara keseluruhan pada kelas eksperimen terdapat 4 indikator yang terkategori sedang, yaitu berpikir lancar $(0,35)$, berpikir luwes $(0,49)$, elaborasi 
$(0,37)$ dan evaluasi $(0,31)$. Sedangkan satu indikator berkategori rendah, yaitu berpikir orisinal $(0,23)$.Tidak ada indikator pada kelas eksperimen yang mendapat kategori tinggi.

Sementara untuk kelas kontrol 4 indikator terkategori rendah, yaitu berpikir lancar $(0,28)$, berpikir luwes $(0,23)$, berpikir orisinal $(0,09)$, dan elaborasi $(0,23)$. Hanya indikator evaluasi $(0,34)$ yang terkategori sedang. Sama halnya dengan kelas eksperimen, pada kelas kontrol ini tidak adaindikator yang memperoleh kategori tinggi. Berdasarkan peningkatan nilai N-gainnya dapat dikatakan bahwa peningkatan keterampilan berpikir kreatif untuk kelas eksperimen lebih tinggi dibandingkan kelas kontrol.

\section{Pembahasan}

Berdasarkan hasil penelitian, pembelajaran JiTT dengan bantuan website lebih mampu meningkatkan keterampilan berpikir kreatif siswa dibandingkan dengan pembelajaran JiTT tanpa bantuan website. Feldhusen dan Treffinger (Munandar, 1999) mengemukakan bahwa lingkungan belajar yang kreatif dapat tercipta dengan memberikan pemanasan, adanya diskusi dalam kelompok-kelompok kecil, dan guru bertindak sebagai fasilitator. Pembelajaran JiTT secara umum tergolong ke dalam model pembelajaran yang mampu menciptakan lingkungan kreatif. Karena di dalam tahapan model JiTT juga terdapat kegiatan pemanasan, diskusi dan peran guru yang menjadi fasilitator.

Pembelajaran JiTT yang berbantuan website memperoleh $\mathrm{N}$-gain yang lebih tinggi dari pembelajaran tanpa bantuan website dikarenakan situs web lebih banyak membantu siswa dalam membangun pengetahuan dan keterampilan berpikir mereka. Kegiatan pemberian umpan balik (feedback) pada tahap pemanasan baik berupa pemberian jawaban, komentar maupun bantahan atas pendapat orang lain secara realtime mampu membantu siswa dalam membangun keterampilan mereka dalam berpikir, terutama merangsang mereka untuk berpikir kreatif. Pertanyaanpertanyaan pemanasan tersebut akan dapat menimbulkan minat dan motivasi siswa untuk berperan aktif, merangsang pemikiran kritis, dan merangsang siswa untuk mencari sendiri pengetahuan tambahan (Munandar, 1999). Hal inilah yang tidak terjadi pada tahap pemanasan dengan pembelajaran tanpa situs web. Sehingga pembelajaran JiTT tanpa situs web hanya memperoleh kenaikan N-gain sebesar 0,24 (rendah) sedangkan pada pembelajaran yang menggunakan website memperoleh $\mathrm{N}$-gain sebesar 0,37 (sedang).

Kenaikan N-gain tertinggi pada masing-masing indikator terjadi pada indikator berpikir luwes $(0,49)$ untuk kelas 
eksperimen dan indikator evaluasi $(0,34)$ pada kelas kontrol. Sementara indikator berpikir orisinal mengalami kenaikan terendah, baik pada kelas eksperimen $(0,23)$ maupun kelas kontrol $(0,09)$. Secara umum pembelajaran JiTT berbantuan website cukup membantu siswa dalam meningkatkan keterampilan berpikir lancar, berpikir luwes, elaborasi, dan evaluasi yang ditunjukkan dengan peningkatan N-gain pada kategori sedang. Sedangkan hanya keterampilan berpikir orisinal yang kurang terakomodasi dengan baik oleh pembelajaran ini, sehingga kenaikan N-gainnya hanya berada pada kategori rendah.

Sementara pembelajaran JiTT tanpa bantuan website kurang signifikan dalam meningkatkan keterampilan berpikir kreatif siswa, karena hanya satu indikator keterampilan berpikir kreatif yang terkategori sedang, yaitu indikator evaluasi. Sementara 4 indikator lainnya terkategori rendah.

Indikator berpikir lancar dan luwes pada kelas eksperimen memperoleh $\mathrm{N}$-gain berturut-turut sebesar 0,35 (sedang) dan 0,49 (sedang). Sementara pada kelas kontrol indikator berpikir lancar hanya memperoleh $\mathrm{N}$-gain sebesar 0,28 (rendah) dan berpikir luwes sebesar 0,23 (rendah). Unggulnya perolehan N-gain kelas eksperimen ini dikarenakan pada pembelajaran JiTT berbantuan website terdapat soal-soal pemanasan dimana siswa dituntut langsung untuk memberikan umpan balik (jawaban) atas pertanyaan pemanasan yang ditampilkan di website tersebut. Menurut Munandar (1999) pemberian pertanyaan-pertanyaan terbuka dapat menimbulkan minat dan rasa ingin tahu siswa. Soal-soal pemanasan ini dapat meningkatkan pemikiran kreatif yang menuntut pada sikap belajar yang berbeda, lebih terbuka dan tertantang untuk berperan aktif memberikan gagasangagasan sebanyak mungkin (Munandar, 1999). Upaya siswa untuk berperan dalam memberikan gagasan-gagasan mereka serta mengajukan banyak pertanyaan inilah yang melatih mereka untuk berpikir lancar. Selain itu, karakter dari keterampilan berpikir luwes yang selalu menuntut siswa untuk memikirkan lebih dari satu jawaban, mengajukan banyak pertanyaan dan menjawab dengan sejumlah jawaban cukup terakomodasi dengan baik pada pembelajaran JiTT berbantuan website ini. Sehingga wajar pada kelas eksperimen mengalami peningkatan lebih tinggi dibanding kelas kontrol. Sedangkan pada kelas kontrol, keterampilan berpikir lancar dan luwes hanya mampu dilatihkan secara optimal pada saat siswa melakukan diskusi ruang kelas.

Keterampilan elaborasi pada kelas eksperimen diperoleh sebesar 0,37 (sedang) dan pada kelas kontrol sebesar 
0,23 (rendah). Keterampilan ini banyak dilatihkan pada saat siswa melakukan simulasi maupun melakukan praktikum virtual sebagai bagian dari kegiatan diskusi di kelas. Selanjutnya, untuk keterampilan evaluasi, baik kelas eksperimen dan kelas kontrol memperoleh kenaikan N-gain yang hampir sama. Pada kelas eksperimen diperoleh N-gain sebesar 0,31 (sedang) dan kelas kontrol unggul tipis sebesar 0,34 (sedang).

Keterampilan berpikir yang kurang berkembang dalam pembelajaran JiTT baik yang berbantuan website maupun tanpa bantuan situs web adalah keterampilan berpikir orisinal. Berdasarkan definisinya, keterampilan berpikir orisinal menuntut siswa untuk mampu melahirkan ungkapan yang baru dan unik. Siswa juga dituntut untuk memikirkan cara-cara yang tidak lazim maupun membuat kombinasi-kombinasi yang tidak lazim. Jika ditinjau dari subjek materi pembelajaran dalam penelitian ini, yaitu konsep listrik arus bolak-balik, maka cukup sulit untuk memberikan ruang pada siswa membuat ungkapan-ungkapan baru, kombinasi baru, maupun simbol-simbol baru. Karena ini berkaitan dengan materi fisika yang harus disesuaikan dengan kaidah dan prinsip fisika yang sudah disepakati dan ditetapkan. Inilah yang menjadikan bahwa keterampilan berpikir orisinal kurang terakomodasi dengan baik, dimana pada kelas eksperimen kenaikannya sebesar 0,23 (rendah) dan pada kelas kontrol hanya sebesar 0,09 (rendah).

Secara umum, kenaikan N-gain dari kelas eksperimen maupun kelas kontrol masih terkategori relatif kecil karena di bawah 0,50. Akan tetapi yang perlu dijadikan catatan adalah tidaklah mudah melatihkan kemampuan berpikir kreatif pada siswa dalam waktu dan proses yang relatif singkat. Karena kemampuan ini berkaitan dengan keterampilan berpikir tingkat tinggi lainnya dan membutuhkan proses berpikir yang mendalam. Munandar (1999) mengatakan bahwa keterampilan berpikir kreatif ditekankan pada menemukan banyaknya kemungkinan jawaban terhadap suatu masalah. Sementara, proses mendapatkan banyaknya kemungkinan jawaban tersebut didasari pada kemampuan untuk membuat kombinasi baru berdasarkan data, informasi atau unsur yang ada. Data dan informasi tersebut diperoleh tidak hanya dari bangku sekolah, melainkan dari keluarga dan masyarakat (lingkungan). Sehingga melatihkan keterampilan berpikir kreatif membutuhkan proses dan waktu yang relatif panjang.

\section{Kesimpulan}

Berdasarkan penelitian yang telah dilakukan tentang model pembelajaran 
JiTT berbantuan website pada topik listrik arus bolak-balik dapat disimpulkan bahwa penerapan model JiTT berbantuan website pada topik listrik arus bolak-balik dapat lebih meningkatkan keterampilan berpikir kreatif siswa dibandingkan dengan pembelajaran JiTT tanpa bantuan website.

\section{Daftar Rujukan}

Armiza. (2007). Model Siklus Belajar Abduktif Empiris untuk Meningkatkan Pemahaman Konsep dan Keterampilan Berpikir Kritis Siswa SMP pada Materi Pemantulan Cahaya. Tesis pada SPs UPI: Tidak diterbitkan.

Depdiknas. (2005). Rencana Strategis Departemen Pendidikan Nasional 2005-2009.[Online].

Tersedia:http://www.slideshare.net/ smpbudiagung/ rencana-strategisdepdiknas-20052009/download[22

Juli 2011].

Depdiknas. (2007). Peraturan Menteri Pendidikan Nasional Republik Indonesia Nomor 41 tahun 2007. [online]. Tersedia: http://akhmadsudrajat.files.wordpre ss.com/2009/04/standar-prosespermen-41-2007_.pdf[22 Juli 2011].

Formica, S. P., Easley, J. L., dan Spraker, M. C. (2010). Transforming common-sense beliefs into Newtonian thinking through JustIn-Time Teaching. Physics Education Research 6.
Fraenkel, J. R., dan Wallen. (2008). How to Design and Evaluate Research in Education. New York : McGraw Hill.

Fitriana, I.S. (2010). Penggunaan Multimedia Interaktif (MMI) dalam Proses Pembelajaran Materi Teori Kinetik Gas untuk Meningkatkan Pemahaman Konsep dan Keterampilan Berpikir Kreatif Siswa SMA. Tesis pada SPs UPI: Tidak diterbikan.

Kaharu, S. (2010). Penggunaan Hypermedia untuk Meningkatkan Pemahaman Konsep dan Kemampuan Berfikir Kreatif Mahasiswa dalam Pembelajaran Rangkaian Listrik Arus Searah. Tesis pada SPs UPI: Tidak diterbitkan.

Mason, R., dan Rennie, F. (2010). Elearning: Panduan Lengkap Memahami Dunia Digital dan Internet. Yogyakarta: Baca.

Mubaraq, L. (2009). Model Pembelajaran Berbasis Web pada Materi Fluida Dinamis untuk Meningkatkan Penguasaan Konsep dan Keterampilan Generik Sains Siswa.Tesis pada SPs UPI: Tidak diterbitkan.

Munandar, U. (2012). Pengembangan Kreativitas Anak Berbakat. Jakarta: Rineka Cipta.

(1999). Mengembangkan Bakat dan Kreativitas Anak Sekolah. Jakarta: Gramedia. 
Novak, G. M. (1999). Just in Time Teaching. [Online]. Tersedia: http://webphysics.iupui.edu/jitt/wh at.html [18 Desember 2012]

Novak, G. M., Patterson, E.T. (1998). Just-in-Time Teaching: Active Learner Pedagogy with WWW. IASTED International Conference on Computers and Advanced Technology in Education.

Ornek, F., Robinson, W. R., Haugan, M. R. (2007). What Makes Physics Difficult. Science Education International, 2007, Vol. 18.

Patterson, E. T. (2005). Just-in-Time Teaching: Technology Transforming Learning - A Status Report. Invention and Impact:
Novak, G. M., Middendorf, J. (2004). What Works - A Pedagogy Just-inTime Teaching. In:Volume IV What Works, What Matters, What Lasts. Project Kaleidoscope.

Building Excellence in Undergraduate STEM (Science, Technology, Engineering, and Mathematics) Education: American Association for the Advancement of Science.

Solikhin, J. R. (2012). Pengaruh Model Just-In-Time Teaching (JiTT) Terhadap Penguasaan Konsep dan Keterampilan Proses Sains dalam Pembelajaran Fisika pada Konsep Hukum Newton.Tesis pada SPs UPI: Tidak diterbikan. 